\title{
FACTORS ASSOCIATED TO USUAL PHYSICAL ACTIVITY IN WOMEN
}

\author{
FATORES ASSOCIADOS À PRÁTICA DE ATIVIDADE FÍSICA HABITUAL EM MULHERES
}

FACTORES ASOCIADOS CON LA PRÁCTICA DE ACTIVIDAD FÍSICA HABITUAL EN MUJERES

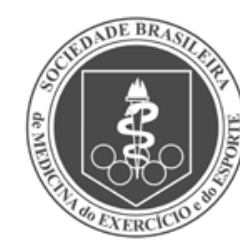

Artigo Original

OrIGINAL ARTICLE

Artículo Original
Paulo André Medeiros de Oliveira' (Educador Físico)

Alexandrina Gomes de Oliveira ${ }^{1}$ (Educadora Física)

Ana Cristina Tillmann' (Educadora Física)

Camila da Cruz Ramos de Araujo ${ }^{1}$ (Educadora Física)

Cecilia Bertuol $^{2}$

(Educadora Física)

Joris Pazin

(Educador Físico)

Mariana Rocha ${ }^{1}$

(Educadora Física)

Melissa de Carvalho Souza

(Educadora Física)

Sara Feltrin Jeremias'

(Educadora Física)

Vanessa Terezinha Ferrari Jonck'

(Educadora física)

Zenite Machado'

(Educadora Física)

Adriano Ferreti Borgatto²

(Estatístico)

Adriana Coutinho de Azevedo

Guimarães' (Educadora Física)

1. Universidade do Estado de Santa Catarina- UDESC, Florianópolis,

Santa Catarina, Brasil.

2. Universidade Federal de Santa

Catarina - UFSC, Florianópolis, Santa Catarina, Brasil.

\section{Correspondência:}

Rua Bernardo Halfeld, 364, Roçado, 88110-695. São José-SC, Brasil. pauloandre.ef@hotmail.com

\begin{abstract}
Introduction: attention has been focused on investigating the prevalence of physical activity (PA) in different populations. Objective: to analyze factors associated with the usual practice of PA in women from areas of Santa Catarina, Brazil. Methods: the cross-sectional study enrolled a sample of 2750 women with a mean age of $32.97 \pm 10.9$ years. PA was assessed by the International Physical Activity Questionnaire (IPAQ). The sample was divided into six groups: (Southern Region; Itajaí Valley; Northern Region; Western Region; Highlands Region and the Greater Florianópolis Region, SC, Brazil). Statistical analysis was descriptive and inferential. Results: approximately $68.3 \%$ of women were considered sufficiently active (active + very active), in particular the Greater Florianópolis Region, SC, Brazil. In the practice of moderate and moderate + vigorous activity, the women of Western Region presented the highest averages ( $65 \pm 64 \mathrm{~min} / \mathrm{d} ; 105 \pm 102 \mathrm{~min} / \mathrm{d}$ ), respectively, and those in the range of 20-32 years old showed $61 \%$ chance of being considered active compared with women in the range of $46-59$ years old. As for the body mass index (BMI), women with normal weight of the South Region and Itajaí Valley regions had 2.24 (95\% Cl;1.15-4.35) and 1.76 (95\% Cl; 1.14-2.73) times more chances to be active when compared to the overweight women. Conclusion: women in the regions of Santa Catarina were considered sufficiently active. Moderate + vigorous PA was the most prevalent in the six regions studied.
\end{abstract}

Keywords: exercise, health, women.

\section{RESUMO}

Introdução: a atenção tem se concentrado na investigação da prevalência de atividade física (AF) em diferentes populações. Objetivo: analisar os fatores associados à prática de AF habitual em mulheres em regiões de Santa Catarina, Brasil. Métodos: o estudo transversal obteve amostra de 2750 mulheres, com média de idade de 32,97 $\pm 10,9$ anos. AAF foi avaliada pelo Questionário Internacional de Atividade Física (IPAQ). A amostra foi dividida em seis grupos: (Região Sul; Região do Vale do Itajaí; Região Norte; Região Oeste; Região Serrana e Região da Grande Florianópolis, SC, Brasil). A análise estatística foi descritiva e inferencial. Resultados: aproximadamente $68,3 \%$ das mulheres foram consideradas suficientemente ativas (ativas + muito ativas), destacando-se as da Região da Grande Florianópolis. Na prática de atividade moderada e moderada + vigorosa, as mulheres da Região Oeste apresentaram as maiores médias (65 \pm 64 ; $105 \pm 102 \mathrm{~min} /$ dia), respectivamente, e as de 20 a 32 anos apresentaram $61 \%$ de chance de serem consideradas ativas com relação às mulheres de 46 a 59 anos. Quanto ao índice de massa corporal (IMC), as mulheres com peso normal das Regiões Sul e Vale do Itajaí, apresentaram 2,24 (IC 95\% = 1,15-4,35) e 1,76 (IC 95\% =1,14-2,73) vezes mais chances de serem ativas quando comparadas às mulheres acima do peso. Conclusão: as mulheres das regiões de Santa Catarina foram consideradas suficientemente ativas. A AF moderada + vigorosa foi a mais prevalente nas seis regiões estudadas.

Palavras-chave: exercício, saúde, mulheres.

\section{RESUMEN}

Introducción: los estudios han sido dirigidos a investigar la prevalencia de actividad física (AF) en diferentes poblaciones. Objetivo: Analizar los factores asociados con la práctica habitual de actividad física en las mujeres de regiones de Santa Catarina, Brasil. Métodos: este estudio transversal obtuvo muestra de 2750 mujeres con edad promedio de 32,97 $\pm 10,9$ años. La AF se evaluó mediante el Cuestionario Internacional de Actividad Física (IPAQ). La muestra fue dividida en seis grupos: (Región Sur; Valle de Itajaí; Región Norte; Región Occidental; Región Montañosa y Gran Florianópolis). El análisis estadístico fue descriptivo e inferencial. Resultados: aproximadamente el $68,3 \%$ de las mujeres se consideraron suficientemente activas (activa + muy activa), destacando la región de la Gran Florianópolis, SC, Brasil. En la práctica de actividad moderada y moderada + vigorosa, las mujeres de la Región Occidental presentaron los promedios más altos $(65 \pm 64 ; 105 \pm 102 \mathrm{~min}$. dia), respectivamente, y las de 20 a 32 años tenían $61 \%$ de probabilidad de ser consideradas activas en comparación con las mujeres de 46 a 59 años. En cuanto el índice de masa corporal (IMC), las mujeres con peso normal de las Región Sury del Valle de Itajaí, presentaron 2,24 (IC del 95\%; 1,15-4,35) y 1,76 (IC del 95\%; 1,14-2,73) veces más probabilidades de ser activas en comparación con las mujeres con sobrepeso. Conclusión: las mujeres en las regiones de Santa Catarina se consideraron suficientemente activas. La actividad física moderada + vigorosa fue la más prevaleciente en las seis regiones estudiadas.

Palabras clave: ejercicio, salud, mujeres. 


\section{INTRODUCTION}

Studies have been directed to investigate the prevalence of PA in different populations ${ }^{1}$. The international literature related to PA has been showing rapid growth. In a study, carried out in 20 countries, it has been found that countries such as Japan, Belgium, and Taiwan, reached lower prevalence levels of PA, assessed at a low level, while in the United States, Canada, and New Zealand, physical inactivity has decreased significantly, being possible to find high prevalence ${ }^{2}$.

In Brazil, between the years of 2006 and 2008 only $28.2 \%$ of the population practiced PA regular ${ }^{3}$. In the southern region, it is observed that physical inactivity is significantly lower (13\%) than in the other regions, such as in the Northeast, which reached $16.5 \%{ }^{4}$. In the State of Santa Catarina, specifically in Florianopolis city, the percentage of individuals who practice PA reached $43.1 \%$, considered to be the most active city in the country, and among men it was 54.4\% and 32.9\% among women. The higher prevalence of PA among men, compared to women, was also observed in Victória, Belem, and Manaus (50.1\%; $47.7 \% ; 47 \%)^{4}$. There is a lower tendency of women to the practice of $\mathrm{PA}$, and it may be a result of existing cultural patterns in society ${ }^{5}$.

Despite the evidence related to the PA, in the State of Santa Catarina no studies were found with the studied population, that is, women from 20 to 59 years of age. Therefore, the objective was analize the factors associated with the practice of habitual PA in women from different regions of the State of Santa Catarina.

\section{MATERIAL AND METHODS}

The non-probability sample of convenience was composed by women from 20 to 59 years, living in cities within the region of Santa Catarina with more than 150 thousand inhabitants according to the latest Census, namely Criciúma, Itajaí, Blumenau, Joinville, Chapecó, Lages, Florianópolis, and São José. The present study was approved by Ethics Committee- Research on Human Subjects at the University of the State of Santa Catarina, protocol n 214/2011.

Despite being a non-probability sample, the sample size calculation was carried out according to Barbetta ${ }^{6}$, based on the population of 705,577 women from 20 to 59 years from correspondent cities, 51,606 in Criciúma, 97,497 in Blumenau, 93,262 of Itajaí, 157,177 in Joinville, 55,665 in Chapecó, 46,087 of Lages, 136,558 in Florianópolis, and 67,725 of São José. The calculation of the sample suggests 400 women from each city. At the end of the data collection the total achieved reached 2750 women in the study.

The cities were grouped according to the region of Santa Catarina in which they are located (Southern region: Criciúma; Itajaí Valley: Blumenau and Itajai; Northern Region: Joinville; Western Region: Chapecó; Highland Region: Lages; The Greater Florianópolis Region: Florianópolis and São José).

The women were voluntarily invited to participate through employers or institutions providing services to the level of education, health, justice, religion, and insurance, along with housewives.

A self-administered questionnaire was used concerning age, education, marital status, weight and height (self-referred), for the calculation of body mass index-BMI (weight/height squared). For the classification of BMI (weight status) have used the following cutoff points: underweight (BMl<18.5); regular (BMI 18.5 - 24.9); overweight (BMI 25.0-29.9); overweight and obesity (BMI>30.0)7. For the purposes of analysis, the categories were grouped into: regular weight, underweight and regular weight; overweight: overweight and obesity.

The standard economic classification Brazilian Association of Population Studies (ABEP, 2010), considered the main instrument of segmentation of the population according to their purchasing power, which ranks the population in economic classes as $A, B, C, D$, and $E$, through the conversion of the sum of points concerning the level of schooling of the researched women, and the quantity of consumer goods existing in their residence ${ }^{8}$.

Were collected in a self-administered way through the International PA Questionnaire - IPAQ - short version. In Brazil, this questionnaire has been validated by the Center of Studies of the Laboratory of Physical Fitness of São Caetano do Sul-CELAFISCS, which is the coordinating center of the IPAQ in Brazil. It was considered the number of times each subject held at least 10 continuous minutes of walking, moderate-intensity PA and vigorous intensity in the previous week, in various engagements, namely, work, housework, leisure, sports, and recreation. Considering that, the walk is usually attributed to a 3.3METs requirement level, that is, a level higher than the cutoff value of moderate PA (3METs), the total PA, which results from the summation of the walk, moderate and vigorous activity. It corresponds to an activity of at least moderate intensity. PA was ranked in walk, moderate PA, moderate + vigorous, vigorous, and total activity in minutes/day?

In order to cover a larger number of the population, data collection was carried out via email, and on site. A number of 4,356 questionnaires was distributed, and 2,750 were returned correctly fulfilled, 325 from the South, 594 from the Vale do Itajaí, 351 from the North, 338 from the West, 353 from the Highlands, and 789 from the Greater Florianópolis. In respect of printed questionnaires that were cancelled, 202 were filled in incorrectly, 215 returned blank, and 409 were lost in both the post office and companies. Simultaneously, 80 online answered questionnaire forms were incomplete, 105 did not reach the addressee because the email addresses were incorrect and 595 forms did not return.

\section{Statistical analysis}

The statistical analysis was carried out through the Statistical Package for Social Sciences (SPSS) version 20.0. Descriptive statistics were used by means of the calculation of mean, standard and percent deviation. For the comparison of intensity of PA (walking, moderate and vigorous PA) among regions, ANOVA was used followed by Post Hoc Bonferroni test. The prevalence of PA levels (insufficiently active, active, and very active) was illustrated as a percentage. The comparison of the levels of PA among the six regions and personal characteristics was performed with the Chi Square test.

The Multinomial Logistic Regression Analysis was performed to estimate raw and adjusted odds ratios between the levels of PA, insufficiently active, active, and very active (dependent variables) and demographic variables - gender, age group, schooling, socioeconomic level, marital status, self-referral health, BMI (independent variables). The results found in the raw analysis were used to select the variables in the adjusted analysis, that is, all independent variables that presented $p \leq 0.20$ in the Primary Multinomial Regression analysis were selected in the Adjusted Multinomial Regression.

\section{RESULTS}

The characteristics of the subjects are presented in table 1. Most participants live with a partner (54.3\%), belong to the high socioeconomic status (73.1\%), have graduated in higher education (54.9\%), are aged 20 to 32 years (56.4\%), and have regular weight (61.8\%). For such variables significant differences were found $(p=<0.001)$.

As for PA (table 2), that women in the A Region achieved the lowest means for the variables of moderate, vigorous, moderate + vigorous, and total PA (34 $\pm 55 \mathrm{~min} / \mathrm{d} ; 19 \pm 45 \mathrm{~min} / \mathrm{d} ; 53 \pm 88 \mathrm{~min} / \mathrm{d} ; 94 \pm 114 \mathrm{~min} / \mathrm{d})$, respectively, with significant difference $(p<0.001)$. The women in the $C$ Region presented the highest means in time spent seated during 
week days $(2489 \pm 1690 \mathrm{~min} / \mathrm{d})$, and weekends $(882 \pm 455 \mathrm{~min} / \mathrm{d})$, which is equivalent to $\sim 7$ hours/day, and $\sim 6$ hours/day, respectively, with a significant difference in both variables $(p<0.001)$, and lowest means for walks $(36 \pm 31 \mathrm{~min} / \mathrm{d})$ with a significant difference $(p=0.001)$.

With regard to the level of PA, presented in table 3, most women were considered active or very active, especially those residing in the F Region (51.8\%). The significant difference $(p<0.001)$ shows that the groups present a differential PA level.

Table 4 presents the results obtained in the analysis of Multinomial Logistic Regression among active women of the six regions of Santa Catarina. Region A was identified 2.15 (C195\%= 1.19-3.88) times more susceptible to be physically active among women within regular weight when compared to the overweight women. The younger women aged 20-32 years, in the D Region, presented $61 \%$ less chance of being active concerning the women aged 46-59 years.

As for the odds ratio in insufficiently active women in relation to very active ones, from six regions in Santa Catarina, table 5 observed that women aged $20-32$ years from the B Region, showed $43 \%$ less chance of being active concerning women aged $46-59$ years.
With regard to schooling, those who graduated in elementary and secondary school in the E Region and secondary school of $\mathrm{F}$ Region, presented respectively, 86\%, 59\%, and 36\% less chance to be active in comparison to women who have a higher education diploma. In relation to $\mathrm{BMI}$, women within regular weight from A and B Region presented 2.24 ( $C 195 \%=1.15-4.35)$, and 1.76 $(C 195 \%=1.14-2.73)$ times more likely to be active when compared to overweight women.

\section{DISCUSSION}

Worldwide recommendations about the practice of PA suggest that to be considered sufficiently active it is necessary at least 150 minutes of moderate PA practice per week, or 75 minutes when it comes to vigorous activity ${ }^{10}$. The results of the present study rated women as sufficiently active, by presenting, in all regions studied, levels higher than the recommendations referred to above. It is possible that the high schooling and socioeconomic level are contributing factors to such condition, based on the concept that individuals with higher education degree feature mostly higher levels of PA due to socioeconomic distinctions ${ }^{11}$.

Table 1. Characterization of the female subjects according to regions: South, Itajaí Valley, North, West, Highlands, and Great Florianópolis - SC. 2013.

\begin{tabular}{|c|c|c|c|c|c|c|c|c|}
\hline Variables & Total & Region A & Region B & Region C & Region D & Region E & Region F & $p$ value \\
\hline Schooling (\%) & & & & & & & & $<0.001$ \\
\hline Primary school & 11.2 & 16.9 & 16.3 & 14.2 & 8.7 & 10.2 & 5.6 & \\
\hline Secondary school & 33.9 & 38.5 & 19.7 & 37.9 & 29.0 & 50.1 & 35.2 & \\
\hline Higher education & 54.9 & 44.5 & 63.9 & 47.9 & 62.3 & 39.7 & 59.2 & \\
\hline Marital status (\%) & & & & & & & & $<0.001$ \\
\hline With a partner & 54.3 & 57.0 & 58.2 & 49.6 & 60.2 & 45.5 & 53.7 & \\
\hline Without a partner & 45.7 & 43.0 & 41.8 & 50.4 & 39.8 & 54.5 & 46.3 & \\
\hline Nutritional status (\%) & 61.8 & 54.7 & 59.1 & 59.0 & 59.4 & 63.1 & 68.7 & $<0.001$ \\
\hline Regular weight & 38.2 & 45.3 & 40.9 & 41.0 & 40.6 & 36.9 & 31.3 & \\
\hline \multicolumn{9}{|l|}{ Overweight } \\
\hline Socioeconomic status (\%) & & & & & & & & $<0.001$ \\
\hline High & 73.1 & 70.2 & 59.9 & 76.1 & 93.8 & 40.7 & 88.6 & \\
\hline Middle & 26.5 & 29.8 & 40.1 & 23.9 & 5.0 & 57.3 & 11.4 & \\
\hline Low & 0.4 & -- & -- & - & 1.2 & 2.0 & -- & \\
\hline Age group (\%) & & & & & & & & $<0.001$ \\
\hline 20 to 32 years & 56.4 & 58.3 & 46.4 & 51.6 & 59.5 & 68.5 & 58.8 & \\
\hline 33 to 45 years & 25.9 & 29.2 & 30.0 & 23.4 & 24.3 & 19.5 & 26.0 & \\
\hline 46 to 59 years & 17.7 & 12.5 & 23.5 & 25.1 & 16.3 & 12.0 & 15.2 & \\
\hline
\end{tabular}

Chi-squared test $p<0.05$. South Region = A; Itajai Valley Region = B; North Region = C; West Region = D; Highland Regions = E; Greater Florianópolis Region = F.

Table 2. Characterization of physical activity by female subjects according to regions: South, Itajaí Valley, North, West, Highlands, and Great Florianópolis - SC. 2013.

\begin{tabular}{|c|c|c|c|c|c|c|c|c|}
\hline Variables & Region A & Region B & Region C & Region D & Region $\mathrm{E}$ & Region F & $p$ value & Post hoc \\
\hline Walk (min/d) & $41 \pm 54$ & $55 \pm 57$ & $36 \pm 31$ & $53 \pm 55$ & $55 \pm 51$ & $46 \pm 47$ & $<0.001$ & $C<F, D, E, B$ \\
\hline Mod. PA $(\mathrm{min} / \mathrm{d})$ & $34 \pm 55$ & $61 \pm 60$ & $54 \pm 49$ & $65 \pm 64$ & $61 \pm 63$ & $63 \pm 58$ & $<0.001$ & $A<C, B, E, F, D$ \\
\hline Vig. PA (min/d) & $19 \pm 45$ & $30 \pm 47$ & $36 \pm 42$ & $41 \pm 59$ & $40 \pm 56$ & $54 \pm 58$ & $<0.001$ & $A<B, C, E, D, F$ \\
\hline Mod+vig PA (min/d) & $53 \pm 88$ & $91 \pm 86$ & $90 \pm 75$ & $105 \pm 102$ & $101 \pm 99$ & $104 \pm 91$ & $<0.001$ & $A<C, B, E, F, D$ \\
\hline Total PA & $94 \pm 114$ & $146 \pm 115$ & $126 \pm 88$ & $156 \pm 131$ & $156 \pm 125$ & $150 \pm 114$ & $<0.001$ & $A<C, B, F, D, E$ \\
\hline Sit./week & $1697 \pm 992$ & $1712 \pm 1164$ & $2489 \pm 1690$ & $1679 \pm 1096$ & $1830 \pm 1114$ & $1796 \pm 1278$ & $<0.001$ & $C>D, A B, F D$ \\
\hline Sit./weekend & $611 \pm 356$ & $631 \pm 459$ & $882 \pm 455$ & $724 \pm 433$ & $783 \pm 544$ & $672 \pm 421$ & $<0.001$ & $C>A, B, F, D$ \\
\hline
\end{tabular}

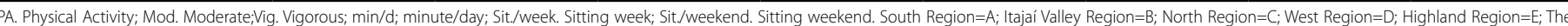
Greater Florianópolis Region=F. ANOVA; Post hoc Bonferroni $-p<0.05$.

Table 3. Physical Activity Level of the subjects according to regions. South, Itajaí Valley, North, West, Highlands, and Great Florianópolis - SC. 2013.

\begin{tabular}{|c|c|c|c|c|c|c|c|c|}
\hline Variables & Total & Region A & Region B & Region C & Region D & Region $\mathrm{E}$ & Region $\mathrm{F}$ & $p$ value \\
\hline PA level (\%) & & & & & & & & $<0.001$ \\
\hline Insufficiently active & 31.7 & 48.3 & 31.0 & 27.4 & 36.9 & 29.9 & 26.0 & \\
\hline Active & 27.8 & 32.2 & 30.1 & 39.3 & 21.3 & 26.7 & 22.2 & \\
\hline Very active & 40.5 & 19.5 & 38.9 & 33.3 & 41.7 & 43.4 & 51.8 & \\
\hline
\end{tabular}


Table 4. Raw and adjusted odds ratio in insufficiently active subjects in relation to the active subjects according to regions. South, Itajaí Valley, North, West, Highlands and Greater Florianópolis - SC. 2013.

\begin{tabular}{|c|c|c|c|c|}
\hline Variables & $\begin{array}{c}\text { PA Level Raw } \\
\text { OR (CI95\%) }\end{array}$ & ${ }^{*} \mathrm{p}$ valor & \begin{tabular}{|c|} 
PA Level Adjusted \\
OR (CI95\%)
\end{tabular} & ${ }^{* *} p$ Value \\
\hline Age Group (B region) & & 0.053 & & 0.069 \\
\hline 20-32 years & 0.65(0.38-1.11) & & $0.58(0.32-1.04)$ & \\
\hline $33-45$ years & $0.56(0.32-1.08)$ & & $0.67(0.33-1.23)$ & \\
\hline 46-59 years & Reference & & Reference & \\
\hline Age Group (C region) & & 0.010 & & 0.001 \\
\hline 20-32 years & $0.41(0.21-0.81)$ & & $0.22(0.09-0.56)$ & \\
\hline $33-45$ years & $0.81(0.37-1.84)$ & & $0.70(0.30-1.64)$ & \\
\hline $46-59$ years & Reference & & Reference & \\
\hline Age Group (D region) & & & & 0.031 \\
\hline 20-32 years & & & $0.39(0.17-0.92)$ & \\
\hline $33-45$ years & & & $0.44(0.17-1.17)$ & \\
\hline 46-59 years & & & Reference & \\
\hline Marital Status (E region) & & 0.029 & & 0.049 \\
\hline With a partner & $1.89(1.07-3.37)$ & & $1.93(1.00-3.73)$ & \\
\hline Without a partner & Reference & & Reference & \\
\hline $\begin{array}{c}\text { Socioeconomic status } \\
\text { (C region) }\end{array}$ & & 0.018 & & 0.069 \\
\hline High & $0.42(0.20-0.86)$ & & $0.42(0.16-1.06)$ & \\
\hline Middle & Reference & & Reference & \\
\hline $\begin{array}{c}\text { Socioeconomic status } \\
\text { (F region) }\end{array}$ & & 0.054 & & \\
\hline High & $1.90(0.99-3.65)$ & & & \\
\hline Middle & Reference & & & \\
\hline BMI (A region) & & & & 0.001 \\
\hline Regular weight & & & $2.15(1.19-3.88)$ & \\
\hline Overweight & & & Reference & \\
\hline
\end{tabular}

* The reference is the insufficiently active. South Region $=A$; Itajai Valley Region $=B$; North Region $=C_{;}$West Region $=\mathrm{D}$; Highland Regions $=\mathrm{E}$; Greater Florianópolis Region $=$ F. PA= physical activity

Table 5. Raw and adjusted odds ratio in insufficiently active subjects in relation to the very active subjects according to regions. South, Itajaí Valley, North, West, Highlands and Greater Florianópolis - SC. 2013

\begin{tabular}{|c|c|c|c|c|}
\hline Variables & $\begin{array}{c}\text { PA level Raw OR } \\
(\mathrm{Cl} 95 \%)\end{array}$ & ${ }^{*} p$ & $\begin{array}{c}\text { PA level Adjusted } \\
\text { OR (Cl95\%) }\end{array}$ & ${ }^{* *} p$ \\
\hline Age group (B region) & & & & 0.050 \\
\hline 20-32 years & & & $0.57(0.32-1.00)$ & \\
\hline $33-45$ years & & & $0.76(0.42-1.36)$ & \\
\hline 46-59 years & & & Reference & \\
\hline Schooling years (C region) & & 0.001 & & 0.131 \\
\hline Primary & $5.02(1.89-13.32)$ & & $0.43(0.11-1.70)$ & \\
\hline Secondary & $1.39(0.78-2.51)$ & & $0.62(0.33-1.15)$ & \\
\hline Higher education & Reference & & Reference & \\
\hline Schooling years (E region) & & 0.002 & & 0.001 \\
\hline Primary & $0.20(0.08-0.55)$ & & $0.14(0.04-0.43)$ & \\
\hline Secondary & $0.55(0.32-0.94)$ & & $0.41(0.22-0.77)$ & \\
\hline Higher education & Reference & & Reference & \\
\hline Schooling years (F region) & & 0.004 & & 0.002 \\
\hline Primary & $1.46(0.67-3.17)$ & & $1.61(0.71-3.68)$ & \\
\hline Secondary & $0.59(0.41-0.84)$ & & $0.64(0.44-0.93)$ & \\
\hline Higher education & Reference & & Reference & \\
\hline Socioeconomic & & 0.001 & & 0.228 \\
\hline \multicolumn{5}{|l|}{ Status (C region) } \\
\hline High & $0.31(0.15-0.63)$ & & $0.56(0.21-1.44)$ & \\
\hline Middle & Reference & & Reference & \\
\hline BMI (A region) & & & & 0.018 \\
\hline Regular weight & & & $2.24(1.15-4.35)$ & \\
\hline Overweight & & & Reference & \\
\hline BMI (B region) & & & & 0.011 \\
\hline Regular weight & & & $1.76(1.14-2.73)$ & \\
\hline Overweight & & & Reference & \\
\hline
\end{tabular}

* The reference is the insufficiently active. South Region $=A$; Itajai Valley Region $=B$; North Region $=C ;$ West Region $=\mathrm{D}$; Highland Regions $=\mathrm{E}$; Greater Florianópolis Region $=\mathrm{F}$. PA= physical activity
Corroborating to the above, the results of the present study identified that specifically in the Highlands, and in Greater Florianópolis, women with elementary and secondary school degrees present lower chances to be active when compared to those with a higher education degree. It might be said that individuals with low schooling levels are subject to a reduced chance of engaging in vigorous and leisure activities $^{12}$. Issues related to PA standard, taking into account age, socioeconomic class, and schooling, point out that women with higher purchasing power and higher education level have greater concern for issues related to health, aesthetics, keeping and losing weight, and have more opportunities to access resources and health instructions ${ }^{13}$.

In addition to those factors, the presente study observed a significant difference in levels of PA among women of the six regions. The women from the Greater Florianópolis Region are the ones within higher PA levels compared to the residents in the other regions.

It is relevant to consider that the Greater Florianópolis Region presents a framework to stimulate the adoption of a more active lifestyle. Currently, differentiated spaces are available to the population as a way of walking and running bike lanes, 43 health fitness centers designed to offer outdoor PA for adults and the elderly, 13 municipal parks that allow the practice of PA through ecological trails and walks, and some of these offer recreation areas, bike paths, sports courts, and even beaches and nature reserves ${ }^{14}$. Furthermore, the fact that the city of Florianópolis is based mostly on the Island of Santa Catarina, within the existence of many beaches, may reflect the conclusion that individuals residing in the coast are more active, if compared to the countryside and metropolitan areas ${ }^{15}$.

On verification of characterization of PA practiced, it was found that women in the South Region showed the lowest averages concerning all the intensities of PA. The reduced intensity PA can be a contributing factor to the risk of developing chronic diseases ${ }^{16}$. In line with such statement, IBGE ${ }^{3}$ data revealed that specifically in the city of Criciúma, which is part of the Southern Region, in the year of 2012 there was a high contingent of female mortality by circulatory system diseases, reaching 113 deaths.

In prospect of a healthy lifestyle, based on the practice of regular PA, it is important to take into account the time that the individual remains sitting at work, in transports or at leisure, because such time is directly related to sedentary behavior, and consequently, health damages ${ }^{17}$, considering the association between the sitting time and mortality from all causes, regardless of the level of PA ${ }^{18}$. The present study noticed that higher means in sitting time were observed in women in the Northern Region, as well as those who showed lower prevalence to walking practice. Such results might have occurred as an outcome of which 51.6 percent of women interviewed in this region are between 20 and 32 years of age, the age group in which many are building up their stability at work, attending high school or higher degree.

The associations between PA and sociodemographic factors in women, in this study, showed similar results with what have been reported in the literature, in identifying significant relationships between BMI, age, and schooling with the PA level in different regions of Santa Catarina ${ }^{19}$. In the Southern and the Itajaí Valley Region it was observed that women who are within regular weight have higher chances of being active when compared to those who are overweight, thus, corroborating with other findings, in which, in addition to this factor, it turns out that to be overweight is a determinant characteristic for inappropriate behaviors on $\mathrm{PA}^{20}$.

The associations found between age group and PA in the present study identified that women aged 20 to 32 years, belonging to the Region of Itajaí Valley, showed a reduced chance of being active in 
relation to the ones aged 46 to 59 years. The lowest prevalence of PA practice in younger women compared to the older women may be attributed to the age factor, older women are in the transition phase between the exit from the labor market and the arrival of retirement. There is a reduction of sedentary behavior, through the reduction of sitting time, considering that such women tend to have an increase in the practice of activities involving the walking ${ }^{21}$.

The present study presents some limitations, such as the assessment of PA by means of self-related information, which could overestimate the behavior because it is a practice considered desirable 22 . The fact that the study involves a nonprobability sample prevents the results to be spread to the entire female population of Santa Catarina. Considering it as a cross-sectional study, the possibility of reverse causality prevents observations of cause and effect.

The facts of covering different areas of Santa Catarina, using a global standard questionnaire on PA (IPAQ), being the most widely used instrument in Brazil ${ }^{23}$, and being based on sample of sufficient size to allow for stratification by region and enabling relevant differences regarding daily PA practice to be detected, some advantages may be considered towards the present study.

\section{CONCLUSION}

This study allowed us to stipulate the practice of habitual PA in the female population of six regions of Santa Catarina and also to acknowledge the factors associated. The outcomes of the research represent useful information for management in health, being such an incentive for intervention in public health. The construction of leisure areas and the elaboration of programs towards behavior change and encouraging adoption of a healthier and more active lifestyle, may contribute to the increased populational PA level.

All authors have declared there is not any potential conflict of interests concerning this article.

\section{REFERENCES}

1. Hallal PC, Matsudo SM., Matsudo VKR, Araújo TL, Andrade DR, Bertoldi AD. Physical activity in adults from two Brazilian areas: similities and differences. Cad Saude Pública. 2005;21(2):573-80.

2. Bauman A, Bull F, Chey T, Craig CL, Ainsworth BE, Sallis JF, et al. The international prevalence study on physical activity: results from 20 different countries. Int J Behav Nutr Phys Act. 2009;6:21.

3. Instituto Brasileiro de Geografia e Estatística (IBGE). Programa Nacional de Amostra por Domicílio. Brasilia, DF: IBGE; 2008

4. VIGITEL Brasil 2012. Vigilância de fatores de risco e proteção para doenças crônicas por inquérito telefônico. Secretaria de Vigilância em Saúde. Secretaria de Gestão Estratégica e Participativa. Brasília (DF): Ministério da Saúde; 2013.

5. Matsudo VK, Matsudo SM, Araújo TL, Andrade DR, Oliveira LC, Hallal PC. Time trends in physical activity in the state of Sao Paulo, Brazil: 2002-2008. Med Sci Sports Exerc. 2010;42(12):2231-6.

6. Barbetta PA. Estatística aplicada às ciências sociais. 7a ed. Florianópolis: UFSC; 2008.

7. World Health Organization (WHO). The International Classification of adult underweight, overweight and obesity according to BMl, 2004. Disponível em: http://apps.who.int/bmi/index.jsp?introPage=intro_3. html. Acesso em: 23 de julho 2011

8. ABEP. Associação brasileira de empresas de pesquisa. O novo critério padrão de Classificação Econômica Brasil, 2010. Disponível em: http://www.abep.org/novo/Content.aspx?ContentID=301. Acesso em: 03 de setembro de 2011.

9. Pardini R, Matsudo S, Matsudo TAV, Andrade E, Braggion G, Andrade D, et al. Validation of the international physical activity questionnaire (IPAQ): pilot study in brazilian young adults. Med Sci Sports Exerc. 1997;29(6):S5-S9.

10. World Health Organization 2011 (WHO). Global recommendations on physical activity for health, 18-64 years old. Genebra, Suiça; 2011

11. Ball K, Salmon J, Giles-Corti B, Crawford D. How Can Socio-Economic Differences in physical activity among women be explained? a qualitative study. Women Health. 2006;43(1):93-113.
12. Scheers T, Philippaerts R, Lefevre J. Compliance with different physical activity recommendations and its association with socio-demographic characteristics using an objective measure. BMC Public Health. 2013;13:136

13. Azevedo MR, Araújo CL, Silva MC, Hallal PC. Tracking of physical activity from adolescence to adulthood: a population-based study. Rev Saude Publica. 2007; 41(1):69-75.

14. Prefeitura Municipal de Florianópolis (Brasil). Cidade: Sobre Florianópolis. Disponível em: http://www. pmf.sc.gov.br/. Acesso em: 17 out 2013.

15. Florindo AA, Hallal PC, Moura EC, Malta DC. Prática de atividades físicas e fatores associados em adultos Rev Saude Publica. 2009;43(Suppl 2):65-73.

16. Hallal PC, Reichert FF, Siqueira FV, Dumith SC, Bastos JP, da Silva MC, et al. Correlates of leisure-time physical activity differ by body-mass-index status in Brazilian adults. J Phys Act Health. 2008;5(4):571-8.

17. Owen N, Healy GN, Matthews CE, Dunstan DW. Too much sitting: the population health science of sedentary behavior. Exerc Sport Sci Rev. 2010; 38(3):105-13.

18. Van Der Ploeg HP, Chey T, Korda RJ, Banks E, Bauman A. Sitting time and all-cause mortality risk in 222497 Australian adults. Arch Intern Med. 2012;172(6):494-500.

19. Bonauto DK, Lu D, Fan ZJ. Obesity prevalence by occupation in Washington State, Behavioral Risk Factor Surveillance System. Prev Chronic Dis. 2014;11:130219.

20. Souza CO, Silva RC, Assis AM, Fiaccone RL, Pinto EJ, Moraes LT. Associação entre inatividade física e excesso de peso em adolescentes de Salvador, Bahia - Brasil. Rev Bras Epidemiol. 2010;13(3):468-75.

21. Godfrey A, Lord S, Galna B, Mathers JC, Burn DJ, Rochester L. The association between retirement and age on physical activity in older adults. Age Ageing. 2014;43(3):386-393.

22. Leijon ME, Stark-Ekman D, NilsenP, et al. Is there a demand for physical activity interventions provided by the health care sector? Findings from a population survey. 2010. BMC Public Health. 2010;10:34.

23. Hallal, PC, Dumith, SC, Bastos, JP, Reichert, FF, Siqueira, FV, Azevedo, MR. Evolução da pesquisa epidemiológica em atividade física no Brasil: uma revisão sistemática. Rev Saude Pública. 2007;41(3):453-60 